\title{
Knowledge Hiding: One of the Primary Reasons behind the Rapid Spread of the Novel Coronavirus COVID-19
}

\author{
Abraham Cyril Issac*
}

\begin{abstract}
The world is battling out the pandemic of Covid-19. The World Health Organization (WHO) is jointly acting upon the same daily, which is evident from the 'situation reports.' The pandemic, which saw its origin in Wuhan, has spread across the world within a short span of under two months. While the pandemic has effectively instilled a situation of cordon sanitaire across the globe, the virus seems to show no respite. This study collates different sources and establishes the human tendency of knowledge hiding as the prime reason for the spread of such colossal magnitudes. The study underlines the notion by examining some of the critical cases and situations that have unfolded in the very recent past.
\end{abstract}

Keywords: Coronavirus; COVID-19; Knowledge hiding; Social distancing

\section{JEL Classification: $\mathrm{M}$}

\section{Introduction}

The world is battling out the pandemic of Covid-19. The World Health Organization (WHO) is jointly acting upon the same daily, which is evident from the 'situation reports.' The pandemic, which saw its origin in Wuhan, has spread across the world within a short span of under two months (Lai et al., 2020). The gravity of the situation is underscored by Fig.1, which illustrates the present status (as on 03-05-2021) of the pandemic. The origin of the epidemic is debated, but hardly can there be any two opinions on the cause of the rapid spread of the virus. The relatively long life span of the virus, especially on metallic surfaces, makes it easily transmittable and harder to contain (Xu et al., 2020). While the pandemic has effectively instilled a situation of cordon sanitaire across the globe, the virus seems to show no respite (Kannan et al., 2020). This study collates different sources and establishes the human tendency

\footnotetext{
* Abraham Cyril Issac is at Indian Institute of Technology Madras, India and Swinburne University of Technology, Melbourne, Australia.
} 
of knowledge hiding as the prime reason for the spread of such colossal magnitudes. The study underlines the notion by examining some of the critical cases and situations that have unfolded in the very recent past. The nutshell of the study is illustrated in Table 1.

Table 1: Knowledge hiding escalating the Covid-19 cases

\begin{tabular}{|c|c|c|c|c|}
\hline Episodes & Description & Observed case & $\begin{array}{c}\text { Type of } \\
\text { Knowledge } \\
\text { sharing behaviour }\end{array}$ & $\begin{array}{c}\text { Response Event } \\
\text { affected }\end{array}$ \\
\hline $\begin{array}{l}\text { Whistle-blowers } \\
\text { reprimanded }\end{array}$ & $\begin{array}{l}\text { Rebuking of knowledge } \\
\text { sharing nodes by } \\
\text { authorities }\end{array}$ & $\begin{array}{l}\text { Dr. Li Wenliang, one of } \\
\text { the eight whistle-blowers, } \\
\text { reprimanded by authorities } \\
\text { for warning others about a } \\
\text { mysterious pneumonia-like } \\
\text { disease in December }\end{array}$ & Suppressing voice & $\begin{array}{l}\text { Local } \\
\text { transmission }\end{array}$ \\
\hline $\begin{array}{l}\text { Concealing travel } \\
\text { history }\end{array}$ & $\begin{array}{l}\text { Deliberate hiding of } \\
\text { travel history at airports } \\
\text { and other arrival centers }\end{array}$ & $\begin{array}{l}\text { A celebrity singer in } \\
\text { India concealed her travel } \\
\text { history and sneaked out } \\
\text { from the airport }\end{array}$ & $\begin{array}{l}\text { Evasive knowledge } \\
\text { hiding }\end{array}$ & Case finding \\
\hline $\begin{array}{l}\text { Hiding } \\
\text { symptoms }\end{array}$ & $\begin{array}{l}\text { Deliberate concealment } \\
\text { or masking the } \\
\text { symptoms at various } \\
\text { point of medical } \\
\text { investigation }\end{array}$ & $\begin{array}{l}\text { Many travellers taking } \\
\text { medication to mask the } \\
\text { potential fever and an } \\
\text { increase in temperature }\end{array}$ & Playing dumb & Case finding \\
\hline $\begin{array}{l}\text { Non-disclosure } \\
\text { of local travel }\end{array}$ & $\begin{array}{l}\text { Individuals not } \\
\text { disclosing their route- } \\
\text { map of the local travel } \\
\text { they made and possible } \\
\text { potential spread of } \\
\text { infection }\end{array}$ & $\begin{array}{l}\text { An infected individual } \\
\text { in the Kasaragod district } \\
\text { of Kerala, India not } \\
\text { disclosing the path he } \\
\text { travelled from the airport } \\
\text { and further local travel he } \\
\text { made }\end{array}$ & $\begin{array}{l}\text { Knowledge } \\
\text { hoarding }\end{array}$ & Contact tracing \\
\hline $\begin{array}{l}\text { Unable to avoid } \\
\text { mass gatherings }\end{array}$ & $\begin{array}{l}\text { Associations and } \\
\text { institutions failing } \\
\text { miserably to avoid or } \\
\text { re-schedule programmes } \\
\text { which include large } \\
\text { scale public gatherings }\end{array}$ & $\begin{array}{l}\text { A large number of } \\
\text { parties, concerts, wedding } \\
\text { receptions were not } \\
\text { postponed even after } \\
\text { repeated warnings }\end{array}$ & Playing dumb & Public gathering \\
\hline $\begin{array}{l}\text { Hoarding } \\
\text { of essential } \\
\text { commodities }\end{array}$ & $\begin{array}{l}\text { Many essential } \\
\text { commodities including } \\
\text { soaps, sanitizers, masks, } \\
\text { toilet papers are hoarded }\end{array}$ & $\begin{array}{l}\text { Panic buying and hoarding } \\
\text { of essential commodities } \\
\text { observed across the globe }\end{array}$ & Playing dumb & $\begin{array}{l}\text { Community } \\
\text { transmission }\end{array}$ \\
\hline $\begin{array}{l}\text { Authorities } \\
\text { suppressing the } \\
\text { number of cases }\end{array}$ & $\begin{array}{l}\text { The number of } \\
\text { infections reported is } \\
\text { manipulated }\end{array}$ & $\begin{array}{l}\text { Lack of proper testing } \\
\text { facilities or avoiding panic } \\
\text { are often cited as reasons } \\
\text { for fudging the number of } \\
\text { infected cases in a territory }\end{array}$ & $\begin{array}{l}\text { Rationalized } \\
\text { hiding }\end{array}$ & $\begin{array}{l}\text { Case finding } \\
\text { Contact tracing }\end{array}$ \\
\hline
\end{tabular}




\section{Discussion: detrimental effects of knowledge hiding}

Though the origin of the virus is still debated, the earlier symptoms were essentially visible in Wuhan. Many of the whistle-blowers, including Dr. Li Wenliang, were reprimanded by authorities for warning others about a mysterious pneumonia-like disease in December. The inadvertent suppression of voice leads to the uncontrolled local transmission in Wuhan, which has reported one of the largest deaths. Later, when the authorities alerted the world, it had already been late. The next critical instance of hiding is relevant in terms of the deliberate concealment of international travel history at airports (Issac et al., 2020). This facilitated the smooth transfer of viruses across continents. Many relevant examples of deliberate concealment of travel history even after repeated investigations have come out across the world. Such an evasive knowledge hiding strategy has affected the case finding to a great extent.

The further movement of such individuals has augmented the spread of the infection. The discrete use of medication to mask the potential fever and other symptoms associated with the Covid-19 infection amounts to yet another critical dimension of knowledge hiding. This underscores the playing dumb strategy of knowledge hiding and critically affects the case finding (Issac \& Baral, 2019; Connelly et al., 2012). Similar to the deliberate concealment of international travel history, the non-disclosure of local travel is yet another aspect of hiding information.

Such a type of behaviour is describing as knowledge hoarding, and it severely affects all the efforts of contact tracing. It is no more a secret that the public gathering magnifies the spread. Associations and institutions failing miserably to avoid or re-schedule programmes which include large scale public gatherings have indeed increased the pace of the journey of the coronavirus. Unfortunately, a large number of parties, concerts, wedding receptions were not postponed even after repeated warnings, which underscores the playing dumb strategy of knowledge hiding. The hoarding of essential commodities or hiding the availability of the same has also initiated the propagation of the virus spread swiftly. The panic buying has aided in the community transmission of the coronavirus across the globe. Many a time there is reportedly manipulation in data. This is a critical means of rationalized hiding, which does more harm than good. 
Figure 1: Covid-19 infection status as on 05-10-2020

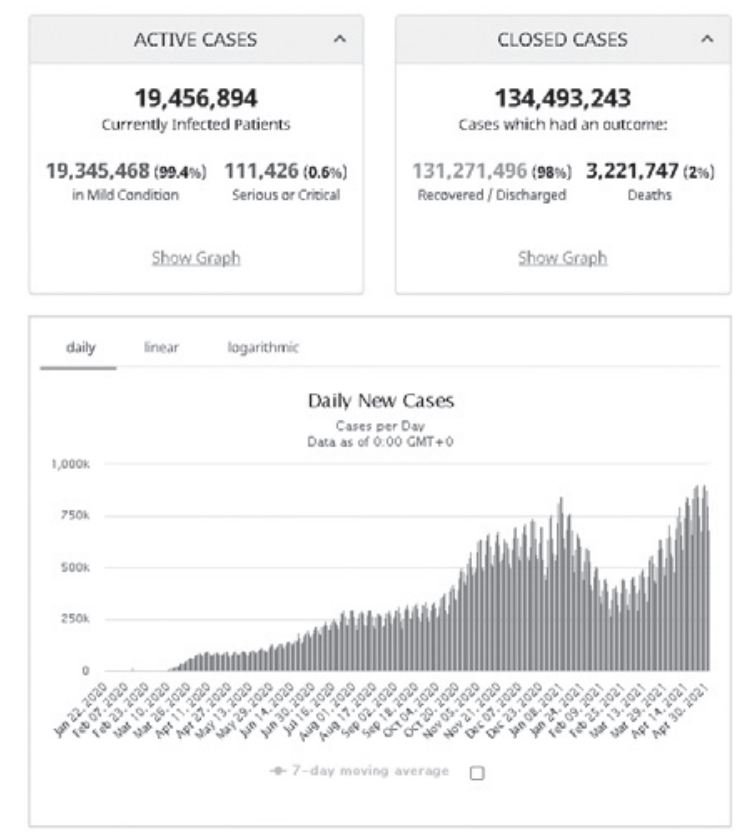

Source: https://www.worldometers.info/

\section{Suggestions to curb the rapid spread of COVID-19}

When the world is fighting a fierce battle against the coronavirus COVID-19, which is taking an unprecedented toll on both the lives of innocent people and the world economy, everyone has to contribute to the mitigation. But critical knowledge hiding activities, as illustrated in Table 1 during this period, will further deteriorate the situation and will instill irrecoverable losses. Around the world, people should understand that this deadly virus could only be controlled by case finding, contact tracing, and suspension of all public gatherings. This can only be achieved by physical distancing (not social distancing) and staying aloof.

The world leaders should listen to expert advice. It is already late; but still the countries which have not employed a strict lockdown are doing a historical blunder. This monumental foolishness will only facilitate in wiping out the mankind from the face of earth. It is time, human beings should rise to the occasion. People should be more open in disclosing their travel history. This will enable the authorities to rightly make a corresponding route map, which effectively can aid in any contact tracing and can ultimately prevent any possibility of local transmission. Avoiding a government scrutiny by deliberately controlling the body temperature with medication to facili- 
tate unwanted travels and activities is nothing short of a sin during this time; as you are undoubtedly putting others also into the clutches of the COVID-19.

The state authorities should be pragmatic in disclosing the number of cases. Sharing the experiences of countries which are successful to some extent in restricting the pandemic is the only way out, A collective approach could only take the world entirely out of this pandemic. Some countries, though have declared lockdown, but are failing miserably in enforcing the same. People wandering in streets in huge numbers will defeat the purpose. People should understand that there are certain limitations with the authorities which inevitably should make them more responsible to themselves and to the entire mankind. This also includes the effort to stay away from panic buying.

We must understand that there is a large section of society which is not in a position to hoard the essential commodities due to their physical and financial status. As the authorities have categorically ensured the availability of the essential commodities, it is the responsibility of every single human being to procure only for one's need and not for one's greed. This panic buying would otherwise cause an equivalent collateral damage, if not more. To conclude, the aforementioned knowledge hiding tendencies will only defeat the purpose. More sharing, caring, and openness is what the world needs now to defeat the pandemic.

\section{REFERENCES}

Connelly, C. E., Zweig, D., Webster, J., \& Trougakos, J. P. (2012). Knowledge hiding in organizations. Journal of organizational behavior, 33(1), 64-88.

Issac, A.C., Baral, R. and Bednall, T.C. (2020), "Don't play the odds, play the man: Estimating the driving potency of factors engendering knowledge hiding behaviour in stakeholders", European Business Review, Vol. 32 No. 3, pp. 531-551. https://doi.org/10.1108/EBR-06-2019-0130

Issac, A.C. and Baral, R. (2020), "Knowledge hiding in two contrasting cultural contexts: A relational analysis of the antecedents using TISM and MICMAC", VINE Journal of Information and Knowledge Management Systems, Vol. 50 No. 3, pp. 455-475. https://doi.org/10.1108/ VJIKMS-09-2019-0148

Kannan, S., ALI, P. S. S., Sheeza, A., \& Hemalatha, K. (2020). COVID-19 (Novel Coronavirus 2019)recent trends. European Review for Medical and Pharmacological Sciences, 24, 2006-2011.

Lai, C. C., Shih, T. P., Ko, W. C., Tang, H. J., \& Hsueh, P. R. (2020). Severe acute respiratory syndrome coronavirus 2 (SARS-CoV-2) and coronavirus disease-2019 (COVID-19): the epidemic and the challenges. International journal of antimicrobial agents, 105924.

Xu, K., Cai, H., Shen, Y., Ni, Q., Chen, Y., Hu, S., ... \& Qiu, Y. (2020). Management of coronavirus disease-19 (COVID-19): the Zhejiang experience. Zhejiang da xue xue bao. Yi xue ban= Journal of Zhejiang University. Medical sciences, 49(1), 0 . 